\title{
Landsat monitoring of playa-lakes in the Spanish Monegros desert
}

\author{
Carmen Castañeda, Juan Herrero and M. Auxiliadora Casterad \\ Soils and Irrigation Department \\ Agri-food Research and Technological Center (C.I.T.A.), Government of Aragón \\ P.O. Box 727, 50080 Zaragoza, Spain. \\ Dr. Juan Herrero Isern \\ Affiliation and Addres actually: \\ Estación Experimental de Aula Dei (EEAD-CSIC) \\ Soil and Water Department \\ Avda. Montañana 1005, Zaragoza (Spain) \\ jhi@eead.csic.es
}

\begin{abstract}
Small playa-lakes in Monegros, Spain, are high-value habitats for endemisms, threatened by landscape transformations and development of newly irrigated lands. The purpose of monitoring these fragile habitats is to detect their future disturbance, i.e., the effects of changing their natural hydrological regime, such as increasing their flooding surface area and habitat degradation by fresh and polluted water flow inputs. Landsat imagery is used for this purpose, facing the lack of regular ground data about their hydrological regime and the land covers with ecological meaning. Five meaningful thematic classes have been established grouping spectral classes obtained from unsupervised classification together with the visual interpretation of the original bands, the IHS transformation and the principal component analysis. The scarce ground data were confronted with the images. Compared to field works, remote sensing is advantageous for monitoring these playa-lakes, providing reliable insight to understand these habitats. Examples of how this research advances our knowledge about the nature and response of this ecosystem to adverse environmental changes are presented.
\end{abstract}

Keywords: wetland, saline depression, remote sensing, endemism; arid environment. 


\section{Introduction}

The Monegros Desert in Aragón (Spain) includes an arheic area with scattered playa-lakes and other closed saline depressions of high scientific and environmental value, being the natural habitats of endemic microbes, plants and animals. These fragile habitats, locally named saladas, are characterized by ephemeral brines alternating with dry conditions and by halophytes distributed according to salt tolerance.

The Spanish Government has launched a project to irrigate over 60,000 ha in southern Monegros, affecting this territory, while the uniqueness of this European region has been already recognized in some patches delineated for bird protection, illustrating a typical conflict between production and conservation. After the irrigation project, this desert and arheic area will receive water conducted from Pyrenean rivers; the project also involves strong landscape transformations due to farm consolidation, and associated works for agricultural intensification.

The forthcoming irrigated lands include the half of the area hosting playa-lakes. Meanwhile, hydrological studies (Berga, 1993; Samper and García-Vera, 1998) assert that irrigation will modify the saline groundwater hydrologic balance and that new fresh and polluted water flows will discharge into the depressions. The result, as we can see in other saladas in Aragón could be a permanent and fresher flood in the depressions and playa-lakes, destroying existing habitats and extinguishing valuable endemic organisms.

One of the problems in monitoring and preserving these playa-lakes is the scarcity of records about their hydrologic conditions and associated environments with ecological meaning. Only some punctual and unpublished ground records are available, 
but remotely sensed data can surrogate ground observations if spectral or other features of the satellite image allow reliable interpretation. Corroborating ground data, even over a limited time span, can increase the satellite information evidential value, facilitating the detection of key factors that condition environmental preservation such as agriculture and irrigation.

A current research review shows an increasing interest in characterizing and monitoring wetlands by remote sensing (Zhang et al., 1997; Lunetta and Balogh, 1999; Frazier and Page, 2000; Houhoulis and Michener, 2000; Munyati, 2000; Chopra et al., 2001). These vulnerable ecosystems are often faced with land use transformation and with changes in the aquifers usually connected to them. Many articles studied have investigated humid and vegetated wetlands threatened by desiccation, and located both in coastal and flood plain environments (Al Saifi and Qary, 1996; Dwivedi et al., 1999; Kasischke and Bourgeau-Chavez, 1997; Rao et al., 1999; Baghdadi et al., 2001). Frequently, these researches aim to detect and delineate the water bodies and estimate their change. For this purpose, some of them have used Landsat imagery, taking advantage of the analysis potential stemming from its spatial and temporal resolution, and the continuity of the image acquisition that began in 1972.

Related to inland wetlands in arid environment, there are examples of remote sensing studies and they show a great variety in the thematic approach and the surface area studied. As an example, Verdin (1996) discriminated ephemeral water bodies of between 1 ha and 150 ha in Nigeria. Drake and Bryant (1994) monitored the flooding ratio of Tunisian playas-lakes sized from $90 \mathrm{~km}^{2}$ to $5500 \mathrm{~km}^{2}$ for study the climatic changes on the playas hydrology, and later Bryant and Rainey (2002) examined the response of these playas to seasonal changes, and the inundation process stages within 
the saline pan were recognized by changes in the surface reflectance properties of the playa-lake bed. Changes in the water extent of playas and closed salt lakes have been estimated by remote sensing to asses changes in regional climate (Schneider et al. 1985; Harris, 1994; Bryant, 1999; Birkett, 2000). Nakayama et al. (1997) detected changes in the water area and volume of Central Asian lakes and related them to environmental parameters. Remote sensing provides a temporal perspective of the playa-lakes hydrology in the lack of historical data such as water levels (Al-Kudhairy et al., 2002).

In Spain, most of the wetland monitoring studies that use remote sensing, have been conducted to assess the water exhaustion because of aquifers pumping for irrigation, while Monegros playa-lakes's main threat is flooding by water flows from irrigated lands. In this way, palaeolimnology provides evidence of the strong impact of irrigation return flows for hundreds of years (Valero-Garcés et al., 2000) in a saline lake $30 \mathrm{~km}$ far from Monegros. Even though the habitats hosted by the Monegros playalakes are now under legal environmental protection, remotely sensed data has not yet been used for decision-making.

The first objective of this present article is to identify the playa-lakes and to set up a methodology to discriminate facies, i.e., surface features being (i) indicators of their hydrological and ecological status, and (ii) detectable both in the field and from remote sensing data. The second objective is to show some examples of the usefulness of our methodology to obtain historical data of playa lakes. For this purpose, Landsat TM and ETM+ images are analyzed and the scarce available historic ground data were contrasted with remotely sensed information. 


\section{Study area}

The study area lies in the Monegros Desert, Aragón, Spain, one of the most arid climates of Europe (Herrero and Snyder, 1997). Rainfall is very irregular, with an annual mean of $388 \mathrm{~mm}$ according to the Bujaraloz weather station, and a mean annual $\mathrm{ET}_{0}$ of $1255 \mathrm{~mm}$ (Faci and Martínez-Cob, 1991).

Southern Monegros is a plain over nearly horizontal Miocene sediments of alternating limestone, gypsum and lutites, with high soluble salts content. Rain water infiltrates along fault and fracture systems related to tectonic stress fields (Arlegui and Soriano, 2003). A constellation of almost 100 topographic closed depressions have been inventoried in this plain, forming the so-called Bujaraloz-Sástago endorheic complex (Figure 1). Some of them are playa-lakes (Briere, 2000), conceptually classified as discharge playas (Yechieli and Wood, 2002), whereas others are small wet saline depressions. Combined effects of groundwater and aeolian processes have produced all these depressions related to gypsum karst (Sánchez et al., 1998). Their geomorphological and hydrogeological features have been described by several authors, as reviewed by Castañeda (2002), providing information about sedimentary processes and paleoclimatic conditions (Schütt, 1998; Valero-Garcés et al., 2001). They produce habitats supporting endemisms and other organisms of high biogeographical interest, making the Monegros playa lakes a matter of environmental concern, as reviewed by Pedrocchi (1998). 


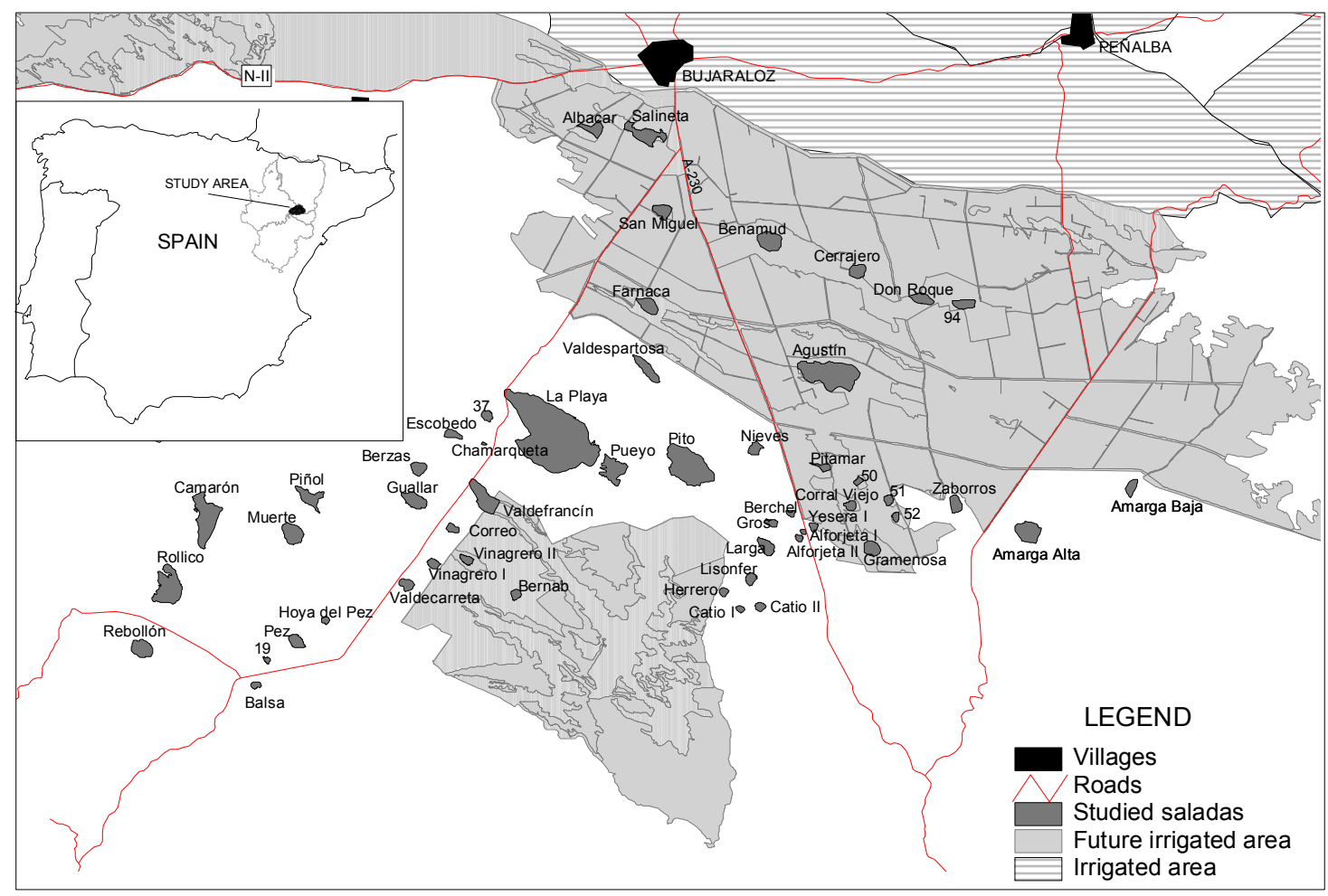

Figure 1. Location of the Monegros playa-lakes.

Monegros playa-lakes play an important role in the regional hydrology. A specific conceptual model was described by Samper-Calvete and García-Vera (1998), who established two underlying semi-confined aquifers having a long time water residence, providing salty waters upwards the playa floor, and allowing water to evaporate from the capillary fringe. The playa bottoms contain brine and salt precipitates studied by Pueyo (1979). The ephemeral brines have a high variable concentration depending on the season, and they are usually transparent although their appearance and color change as salt precipitates and algal mats occur. A playa floor deposit of fine dark mud mixed with organic matter and occasionally covered with white efflorescence forms a flat salt plain. When there is no water in the depressions, the soil surface often remains wet. 
These dark wet surfaces show distinct contrast and net boundary with the light dry soils in the edge of most depressions.

Playa lakes are bare, except for the halophilous vegetation at their fringes (Figure 2). Other closed saline depressions are all covered by halophytes evidencing the saline water table proximity. The transitory water body presence and their extent, condition the distribution of the vegetation and the wet surface.

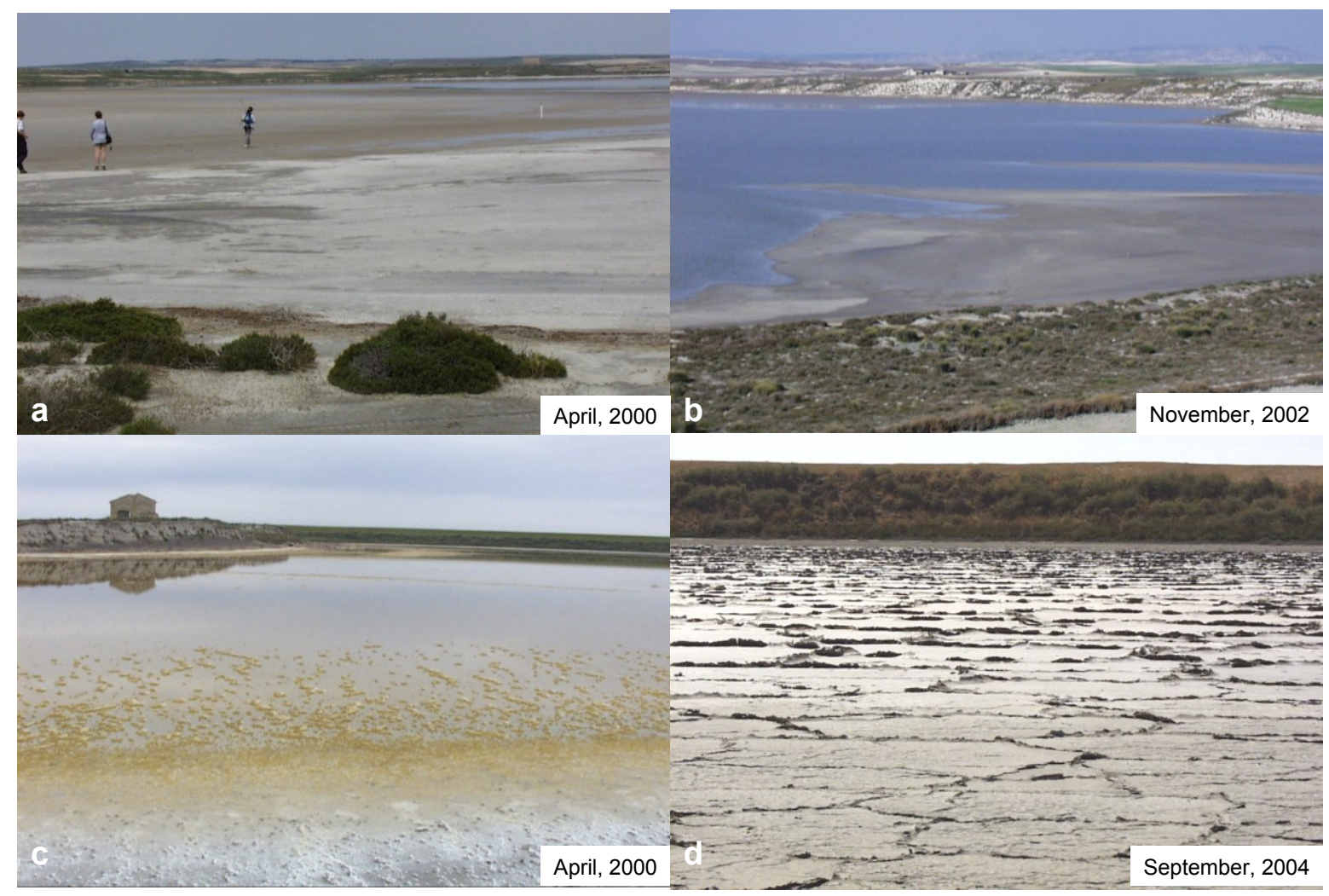

Figure 2. Changing looks of two saladas La Playa (a and b) and Salineta (c and d).

From an environmental and global perspective, Monegros playa-lakes are confined in a vulnerable territory where the landscape changes due to the expansion of the agriculture have been interpreted as a risk of land degradation (Koch, 2000). Although the environmental concerns of European Union blocked the irrigation works for several years, and have enforced the exclusion of some areas from irrigation, the 
playa-lakes are being affected by the new infrastructures and dumping, as observed in recent field studies. These affections have increased because of land consolidation and intensive plow in non-irrigated lands (Figure 3), but the main threaten for playa-lakes as habitats is irrigation progress, clearly visible in the satellite images, being the forthcoming impact the flood episodes duration, extent, and frequency increase, and last but not least the water bodies salinity decrease.

\section{Material: ground data and satellite imagery}

Two ground record sets for the water bodies in the Monegros playa-lakes were available (Table 1). The first set contains the monthly water presence or absence record taken by Berga (1993) from January 1987 to September 1990. Berga monitored the 15 playa-lakes where water presence was more frequent. The second set contains the weekly water depth measurements carried out by the Government of Aragón (Spain), from March 1993 to June 1997, compiled by Castañeda (2002). In this set, water depth was measured on a ruler driven into the ground at eight playa-lake bottoms. The maximum measured water depth was $51 \mathrm{~cm}$.

All these data have been employed to interpret satellite data in spite of the following limitations: (i) the ground data collection was not planned to be used with remotely sensed data, so no information was recorded about the bare soil facies and the land cover around the water, at the bottom of the playa lakes, (ii) the observation dates do not match the satellite image dates. 


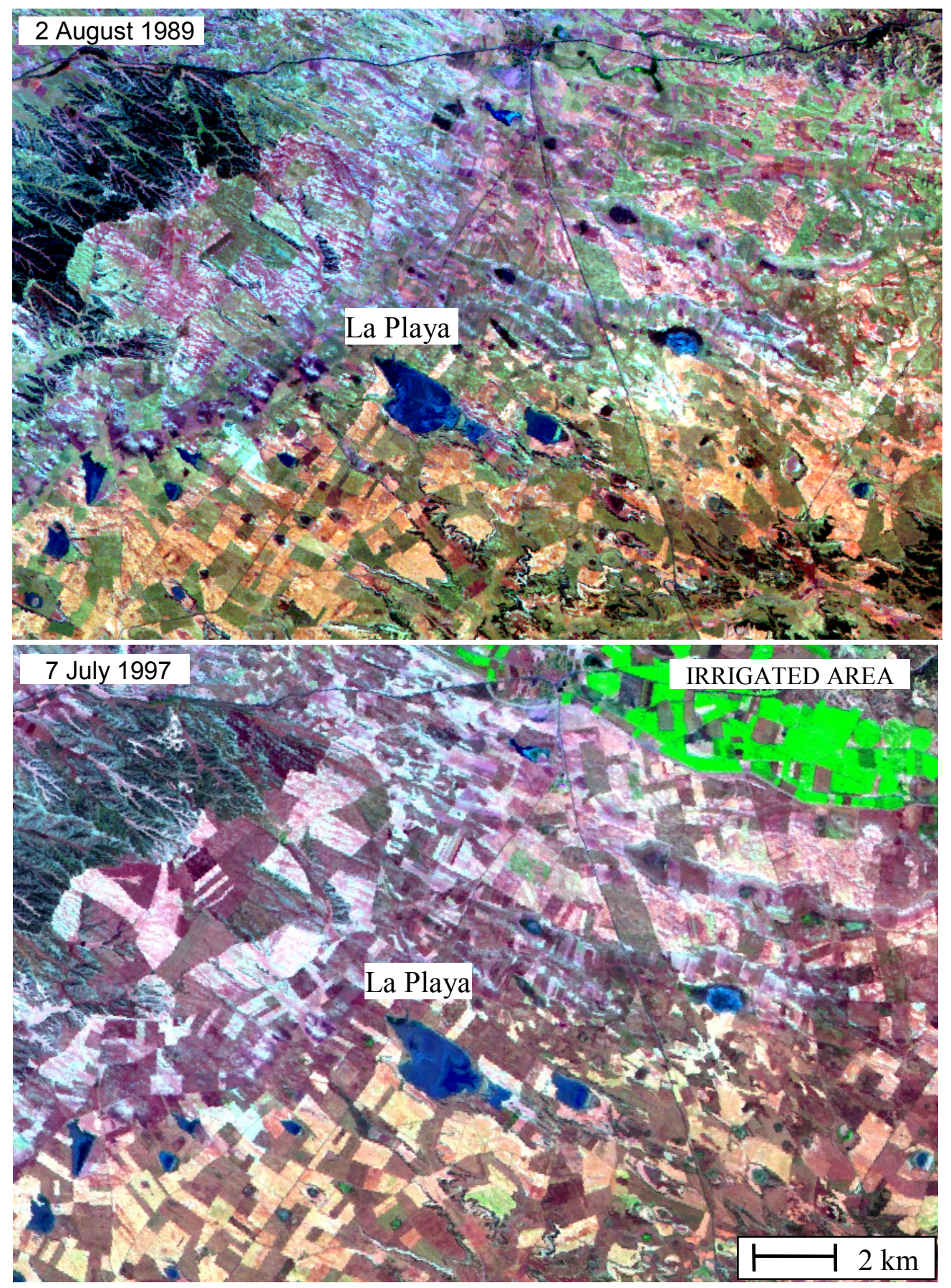

Figure 3. Landsat 5 TM RGB 741 images. Land consolidation and changes in fallow coverage following common agricultural policy are responsible of the different appearance of the dry farmed area in the two dates. The newly irrigated lands (NE corner in 1997 image) advance toward the playa-lakes. Most of them are less than 50 ha, except for La Playa (200 ha), in the middle of the images. 
This study uses 26 Landsat TM and ETM+ images spanning 16 years from 1985 to 2000. A lot of them represent the summer and spring season because they were not acquired for this specific study, but for agricultural purposes. Three winter images were acquired so that dry and humid seasons are represented. Table 1 shows the dates of these images and the periods for the ground observations. From 1985 to 1990, one summer image is available each year, except 1987 where there is also a winter image. From 1993 to 2000 two or three images are available each year, corresponding to summer and spring, except in 1995 where there is only a winter image. In 1991 and 1992 there are no images or ground data.

Table 1. Dates of the 26 satellite images used, and available ground data sources.

\begin{tabular}{|c|c|c|c|c|}
\hline Year & Winter & Spring & Summer & Ground data source \\
\hline $\begin{array}{l}1985 \\
1986\end{array}$ & & & $\begin{array}{l}17 \text { August } \\
23 \text { June }\end{array}$ & No data \\
\hline 1987 & $\begin{array}{c}17 \\
\text { January }\end{array}$ & & 13 August & \\
\hline $\begin{array}{l}1988 \\
1989 \\
1990\end{array}$ & & & $\begin{array}{l}14 \text { July } \\
2 \text { August } \\
20 \text { July }\end{array}$ & Berga, 1993 \\
\hline $\begin{array}{l}1991 \\
1992\end{array}$ & & & & No data \\
\hline $\begin{array}{l}1993 \\
1994\end{array}$ & & $\begin{array}{l}6 \text { March } \\
28 \text { May }\end{array}$ & $\begin{array}{c}12 \text { July } \\
26 \text { June } \\
16 \text { August }\end{array}$ & \\
\hline $\begin{array}{l}1995 \\
1996 \\
1997\end{array}$ & 7 January & $\begin{array}{l}\text { 18 April } \\
\text { 15 June } \\
2 \text { April }\end{array}$ & $\begin{array}{l}20 \text { July } \\
7 \text { July }\end{array}$ & Government of Aragón \\
\hline $\begin{array}{l}1998 \\
1999 \\
2000\end{array}$ & $\begin{array}{c}3 \\
\text { February }\end{array}$ & $\begin{array}{c}7 \text { May } \\
23 \text { March } \\
11 \text { June } \\
17 \text { March }\end{array}$ & $\begin{array}{l}11 \text { August } \\
14 \text { August } \\
8 \text { August }\end{array}$ & No data \\
\hline
\end{tabular}




\section{Methods}

First, the satellite images were corrected. After checking the uniformity of the atmosphere over the scenes, a simple haze compensation procedure (Richards and Jia, 1999) was applied to minimize the influence of path radiance effects (Lillesand and Kiefer, 2000). Observing the radiance recorded over target areas of essentially zero reflectance the histogram minimum method (Chavez, 1988) was applied to every complete scene, subtracting any signal value of those targets from all pixels in every band.

In order to make possible comparison of scenes from different dates the original digital values were transformed into spectral reflectivity values using a simplified model that assumes a lambertian behavior of the surface (Chuvieco, 1996). The procedure implies two phases: (i) ND conversion to radiance values using the sensor calibration coefficients, and (ii) estimation of apparent reflectivity using the solar irradiance value and the image date of acquisition.

Then, a subscene of $400 \mathrm{~km}^{2}$ containing the study area was extracted and registered. For this purpose, the July 1997 image was rectified by taking ground control points from the National Geographic Institute maps at 1:25.000 scale and from the Spanish Army Topographic maps at 1:50.000 scale. The other images were registered to this July subscene. Coefficients were determined by the least square method and reflectance values were resampled by the nearest neighbour method. All images were resampled to form a pixel size of 25 meters. The RMS error was inferior to 0.8 pixels.

Once the images were corrected and resampled, we move to step two: using visual interpretation over the 7 July 1997 image, the most humid year in the studied period, the contours of all the discernible salty depressions were extracted. The outlines were 
digitized on a ground of RGB 453 combined image by transferring contour lines of the topographic maps. The outlined depressions numbered 39, with sizes ranging from 1.8 ha to 200 ha. This resulting silhouette map was used as a filter in every rectified subscene to remove all pixels outside the depressions. The resultant images displaying only the playa-lakes and salty depressions are referred to as "target images".

In the third step we extract information from the target images to identify water surface and their associated facies. Four methods were applied to extract information from satellite images (Castañeda et al., 2001): 1) visual analysis of bands 4 and 5 and RGB 457 composition, 2) IHS transformation, 3) principal components analysis, and 4) unsupervised classification (Figure 4). The first three methods were selected as the most commonly used for temporal comparisons, and have also been used for the specific study of playa-lakes by Al-Saifi and Qari (1996). The unsupervised classification, less mentioned in the literature, was well suited for automatic determination of the area of the classes produced.

The visual analysis of the images was carried out with the support of the above mentioned ground data, and taking into account the annual, monthly, and daily rainfall immediately preceding each image, as recorded at the local weather station. When possible, the spring image was compared with the summer image for the same year to observe the seasonal change in the playa-lake floor. Several factors such as tone, texture, location and seasonal cycle were considered for every band.

In order to enhance the spectral signatures of the playa-lake covers, the IHS transformation (Liu and Moore, 1990; Lillesand and Kiefer, 2000) of the target images was applied at the 432 and 457 compositions. Also the principal component analysis was applied over the six original bands taking advantage of the information 
compression and image enhancement properties of this transformation (Richards and Jia, 1999). Representative images of winter, summer and spring were used to compare the playa-lake hydrologic conditions in different seasons.

Unsupervised classification was carried out for every target image using the ISODATA clustering method (Swain, 1973). A standard deviation of 2 and a convergence threshold of 0.95 were used as statistical parameters. Since a relative large number of initial clusters is desirable in order to ensure that no important information is lost (Cihlar et al., 2000), several classifications of the six original bands were tested, varying the number of clusters from 5 to 30 . Then the spectral classes were grouped according to their spectral and visual features, since both are significant with regard to identifying covers in terms of pattern recognition (Landgrebe, 2003). The transformed divergence (Swain and Davis, 1978) was used to determine the spectral affinity between classes, and their location and shape distribution. The spectral signatures were examined for deducing the type of cover represented by each of them. This thematic meaning was confirmed by the ground data and by the soundness and consistence of the related spatial and temporal distribution of all the covers in different bands and false compositions.

Regarding the correspondences between ground and satellite data, the two sets of ground records were considered. In the first set, the monthly observations of water presence concurrent with the month's image were selected. In the second set, the weekly water depth record closest to the image's date was chosen, by simplifying the depth record into water presence or absence. As there is a time lag between the images and the field records, the monthly and daily rainfall immediately preceding each image, recorded at the Bujaraloz weather station, was computed. 


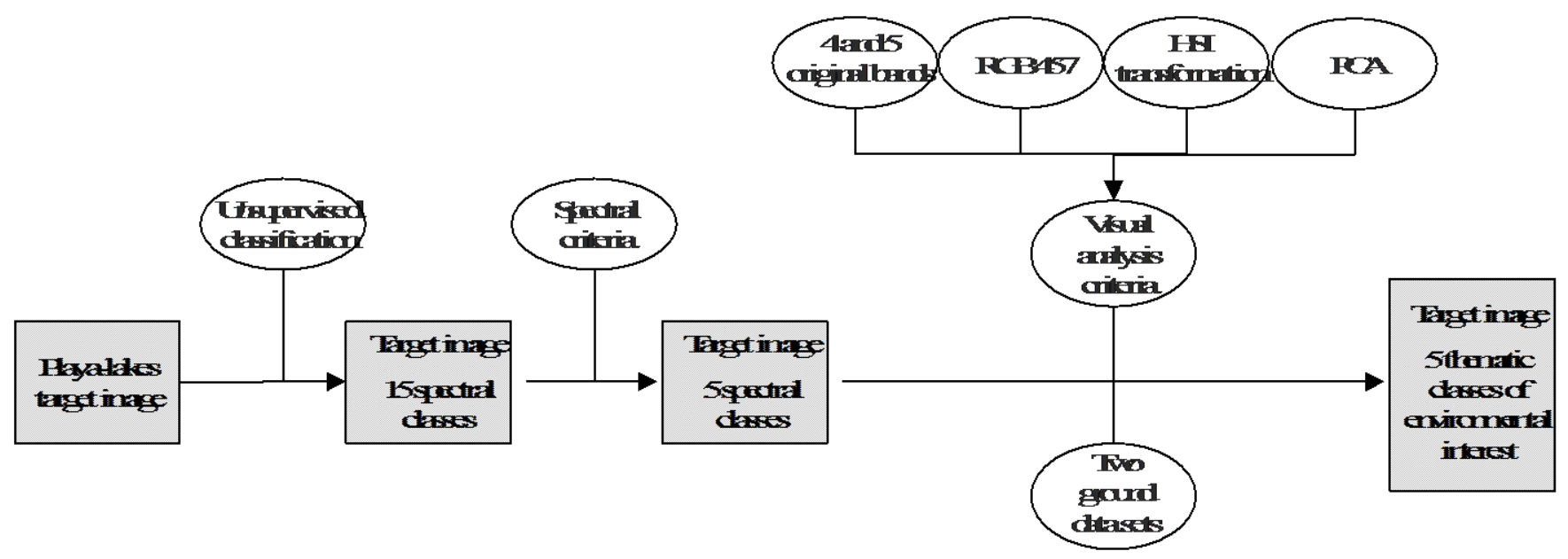

Figure 4. Diagram showing the information extraction process from the target images.

To confirm the thematic meaning of the classes, the IHS and PC images were employed. In these images several factors such as tone, texture, location, seasonal cycle and field knowledge criteria of each thematic class were analyzed. Finally, the surface area covered by every class within every playa-lake was computed and their evolution was obtained.

\section{Results and discussion}

\subsection{Meaningful covers: facies}

In spite of the limitations imposed by the available images, five meaningful classes of ground conditions, named facies, were obtained (Figure 5). These classes are repeatable for all the $26 \mathrm{TM}$ and ETM+ scenes, and their thematic meaning based on our field knowledge of the Monegros wetlands, are: (i) Water: sheet of water with a depth measurable with a ruler scale; (ii) Watery ground: water-imbibed surface, very often forming a discontinuously pooled surface; (iii) Wet Ground: bare soil with high moisture content, often oversaturated but not covered by water, and sometimes having 
organic remains and dry algal mats; (iv) Vegetated Ground: scattered xerophytes and rainfed crops, whose development depends on the season; and (v) Dry Bare Ground: dry land without vegetation. An example of classified images in wet and humid seasons is shown in Figure 4.
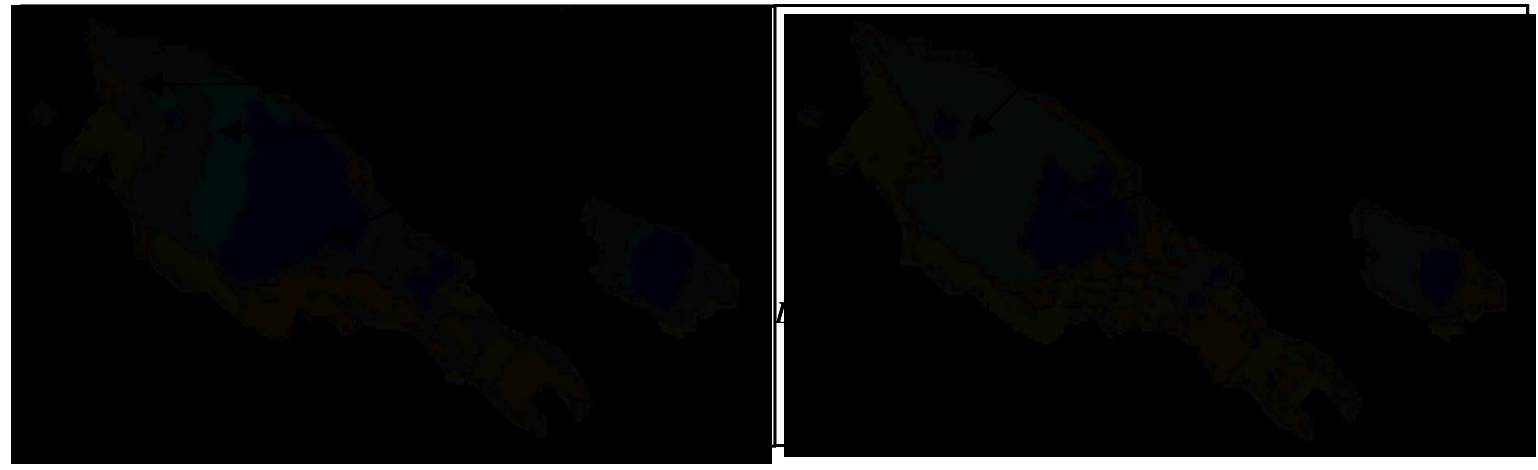

Figure 5. Thematic classes in a fragment of the 2 April 1997 and 7 July 1997 target images.

\subsection{Classification}

The unsupervised classification of 15 clusters was chosen since it was the first in discriminating the shallow sheet of water into the playa-lakes and also was coherent with the visual inspection of the original bands, IHS and PC images. Classifications using 20 and 30 clusters were rejected, as they didn't furnish any new and independent class. The 15 clusters were grouped in 5 final classes, each with a common spectral behavior whose mean reflectance values are displayed in Figure 6. These 5 classes represent all the detected land covers in the playa-lakes, and show a good agreement with both the RGB 457 target images and the IHS transformations, as well as with the ground data when available. 


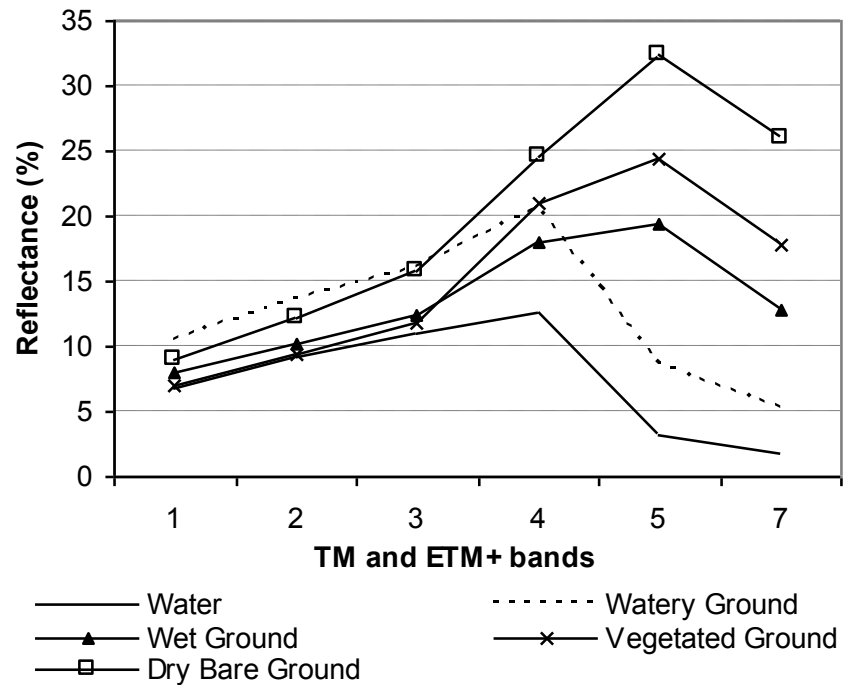

Figure 6. Mean reflectance values of the five spectral classes, named by their thematic meaning.

These five final spectral classes established in the playa-lakes have good separability, reaching transformed divergence (Swain and Davis, 1978) values rarely lower than 1500. The best discrimination arises between the classes representing water presence and the other classes representing waterless surface. The average separability between Water and Watery Ground is higher than 1900. The separability between Dry Bare Ground and Vegatated Ground increases in spring because of the scattered distribution of the vegetation. This spectral separability also was noticed by the good correspondence between unsupervised classification and visual analysis.

\subsection{Complementary analysis}

Table 2 summarizes the result of visual analysis defined by three options: the differentiation of every class is achieved in all the studied images, in none of them, or in only some (Castañeda et al., 2001). The original TM and ETM+ bands, 4 and 5, were 
the more useful bands for visual analysis: whereas band 5 outlines clearly the wet or water surface from the bordering dry surface, band 4 gives a double response inside the water surface, separating Water from Watery Ground. Water depth is revealed by alterations in the spectral energy of the underlying soil as captured by the sensor in this band.

The RGB 457 composition was the best combination for discriminating water and its fringes, as shown by the spring image of 6 March 1993 in La Playa (Figure 7). In this Figure, the color of the water is lighter as the water depth decreases. The presence of algae comes through as a reddish fringe. Wet Ground appears brown. Dry areas show as blue, lighter blue indicating bare soil, while natural vegetation and crops are red, darker as chlorophyllic activity increases.

The best results for the IHS analysis were obtained by transforming the 432 composition. The IHS tone component shows an appearance similar to band 4: in the spring (Figure 8a), Water and Watery Ground can be distinguished at times, as well as a light border stemming from the algal mat. The saturation component (Figure $8 \mathrm{~b}$ ) only detects Water. The intensity component (Figure 8c) does not discriminate Water, and hardly distinguishes Wet Ground from Dry Bare Ground.

The RGB ISH composition detects Water, Wet Ground, Vegetated Ground and Dry Bare Ground with contrasted colors, similar to Ángel-Martínez (1994). In Figure $8 \mathrm{~d}$, the color cyan (saturation + hue) represents Water. The algal mat is strong magenta (hue) while Vegetated Ground is green (intensity), brighter for higher chlorophyllic activity and Dry Bare Ground is orange. 
Table 2. Thematic classes established, and their visual analysis checking.

\begin{tabular}{|c|c|c|c|c|c|c|}
\hline \multirow{2}{*}{\multicolumn{2}{|c|}{ Visual analysis }} & \multicolumn{5}{|c|}{ Classes established by unsupervised classification } \\
\hline & & Water & $\begin{array}{l}\text { Watery } \\
\text { Ground }\end{array}$ & $\begin{array}{c}\text { Wet } \\
\text { Ground }\end{array}$ & $\begin{array}{l}\text { Vegetated } \\
\text { Ground }\end{array}$ & $\begin{array}{l}\text { Dry Bare } \\
\text { Ground }\end{array}$ \\
\hline \multirow[b]{3}{*}{ Original bands } & Band 4 & Yes & Yes & Yes & Yes & Yes \\
\hline & Band 5 & No & No & Yes & Yes & Yes \\
\hline & $\begin{array}{c}\text { Multispectral } \\
\text { image } \\
457 \text { RGB }\end{array}$ & Yes & Yes & Yes & Yes & Yes \\
\hline \multirow{4}{*}{$\begin{array}{c}\text { IHS } \\
\text { transformation }\end{array}$} & Hue image & Yes & Sometimes & Sometimes & No & No \\
\hline & $\begin{array}{l}\text { Saturation } \\
\text { image }\end{array}$ & Yes & No & No & No & No \\
\hline & Intensity image & No & No & No & No & Yes \\
\hline & $\begin{array}{c}\text { composition } \\
\text { RBG HSI }\end{array}$ & Yes & Sometimes & Sometimes & Yes & Yes \\
\hline \multirow{4}{*}{$\begin{array}{l}\text { Principal } \\
\text { component } \\
\text { analysis }\end{array}$} & Component I & Sometimes & No & Yes & No & No \\
\hline & Component II & No & No & No & No & No \\
\hline & $\begin{array}{l}\text { Component III } \\
\text { Color }\end{array}$ & Sometimes & No & No & Sometimes & No \\
\hline & $\begin{array}{c}\text { composition } \\
\text { RGB CI-CII- } \\
\text { CIII }\end{array}$ & Sometimes & Sometimes & Sometimes & Sometimes & Sometimes \\
\hline
\end{tabular}

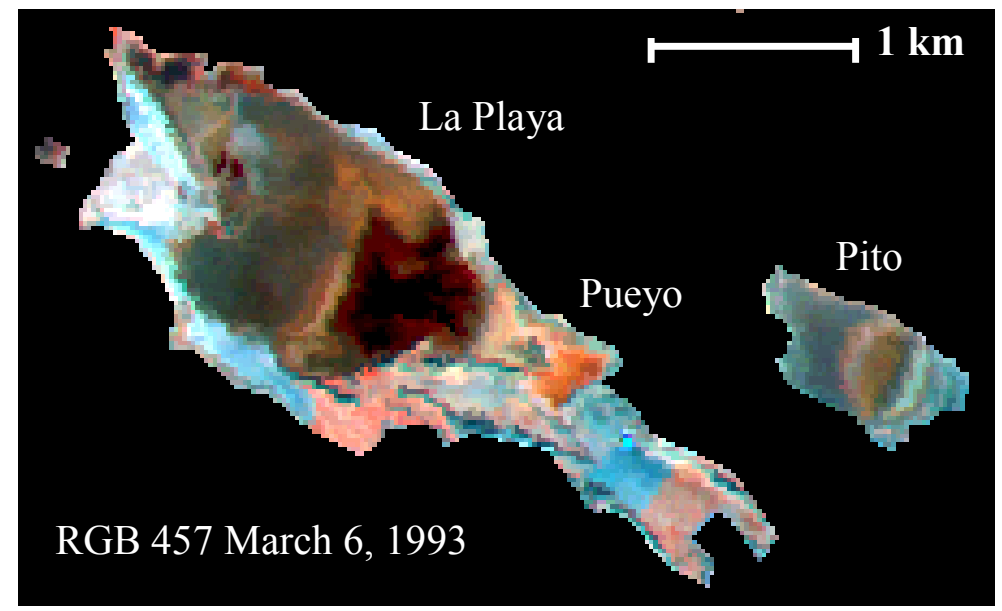

Figure 7. RGB 457 composition for a portion of the target image of 6 March 1993, showing La Playa, Pueyo and Pito playa-lakes. 

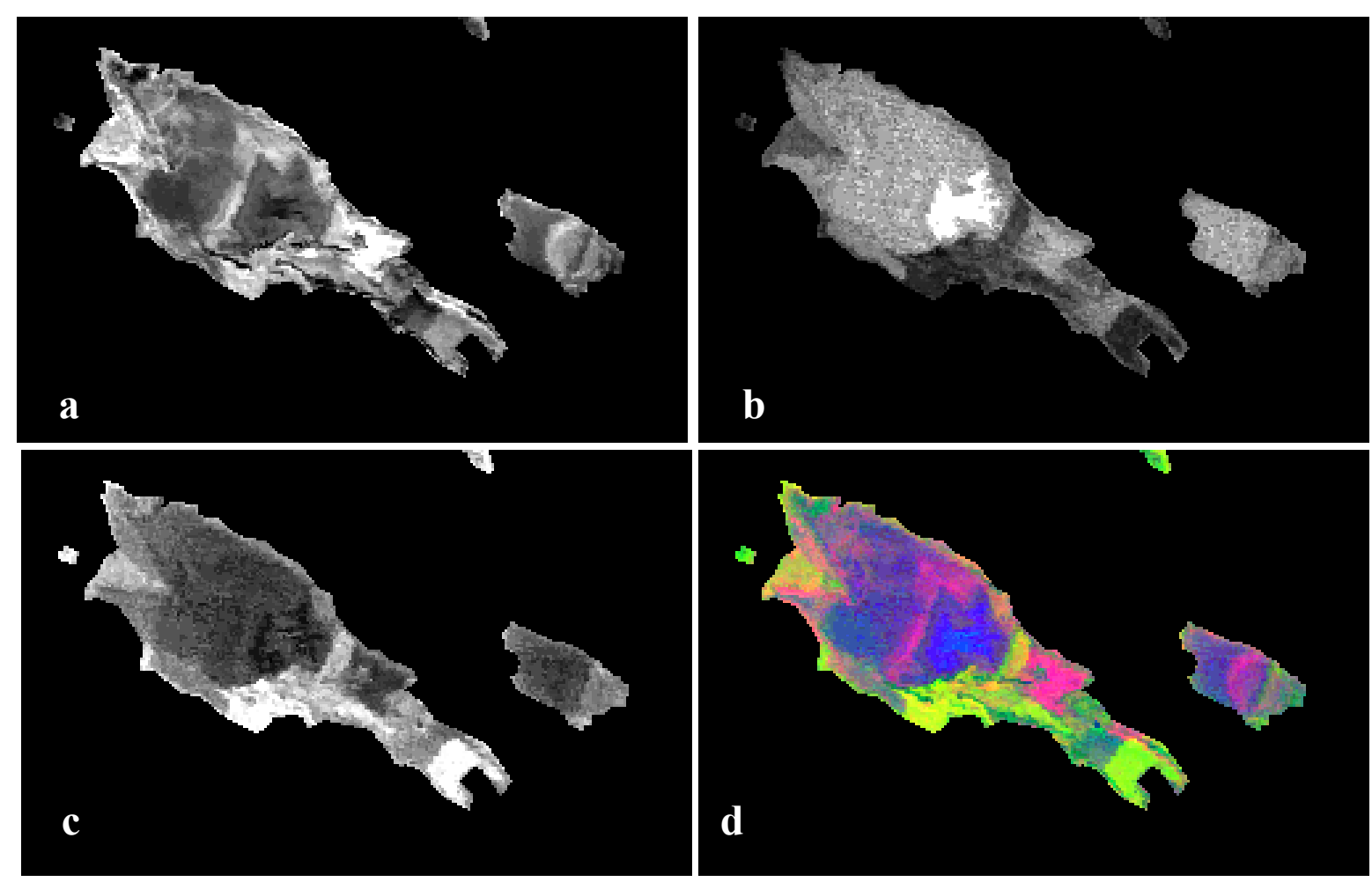

Figure 8. IHS transformation for a portion of the target image of 6 March 1993, showing La Playa, Pueyo and Pito playa-lakes. Hue (a), saturation (b) and intensity (c) components and RBG composition (d).

In the PC analysis, the first three components always retain more than $80 \%$ of the original spectral information. The proportion of each original band included in each of the three components affects its interpretation. These proportions change for each target image but the following general behaviors have been established.

The first principal component (CI) is sometimes similar to band 4 and to the IHS transformation hue component; otherwise, it resembles band 5, and does not distinguish water depth. The second principal component (CII) outlines the wet surface but both the Water and the Dry Bare Ground appear in white. Interpretation of the third principal component (CIII) is more variable and in some target images only part of the Water is distinguished. Neither CII nor CII allow a methodical discrimination in ground covers. 
As the playa-lakes dry, the relative contribution of bands 5 and 7 increase for all the components. The more water there is in the playa-lakes, the greater the contribution of the visible bands $(1,2$ and 3$)$ in CII and CIII.

The color composition RGB CI-CII-CIII does not furnish more information than the original bands. When the lake contains water, this combination is similar to band 4 and even though its colors change with time, the Water, Watery Ground and Dry Bare Ground are all properly defined.

\subsection{Ground correspondence with satellite data}

In spite of the results, some disagreements due to the ground data sets and the satellite date distribution were noticed. The two sets of field records show the water to be occasional in the rainy seasons, whilst in the summer is unusual occurring only in exceptionally humid years or just after a storm. For this reason, many of our images reveal several nearly dry playa-lakes. Also, many of the images were not originally purchased for this specific study, so we could not choose moments when the lakes were almost full. Only in three images, two of them in wintertime, the monitored playa-lakes showed the greatest water extent.

When the ground-based water record differs from the classification image, the disagreement is attributable to the precedent weather and the time lag between the image and the field record. The appearance of these shallow lakes can change in a few days, especially in summer, due to the torrential and local sporadic rains quickly counteracted by high rates of evaporation. Moreover, in some cases a ground data reading of zero doesn't mean water absence. This happens when there is little water in the lake and the wind displaces the water sheet. False zeros also occur when the ruler is 
not located in the deepest site of the lake. Slight changes in the lake bottom topography are the cause for this inconsistency. Only satellite images can identify the presence of water either when the ruler is reading zero, or when Watery Ground forms irregularly scattered ponds.

\subsection{Usefulness of this methodology for planning and conservation.}

Satellites are the only data source to know the past and present status of the saladas. This information is necessary to analyze how irrigating the conterminous land affects these habitats.

Regarding historical surface water conditions in the Monegros playa-lakes, Water rarely occurs in summer, and then only just after a rain or in the more rainy years (Castañeda and Herrero, 2005). Its extent was extremely varied during the period studied. When rain is preceded by long periods of drought, Watery Ground occurs, instead of Water. These changeable covers disappear during the driest periods, but Wet Ground always remains, even in summer.

The information generated with our methodology enables to know the natural hydrologic regime (Castañeda and García, 2004), patterns and trends, in these wetlands (Figure 9). Of special interest is the increase or decrease in Water plus Watery Ground extent, as it relates to irrigation in the surrounding lands. Some saladas will be flooded by the leaching fraction of the irrigation and other return flows, while the installed buried pipes could intercept the natural discharge of groundwater leading to other saladas desiccation. The automatic monitoring will alert about anomalous flooding. 


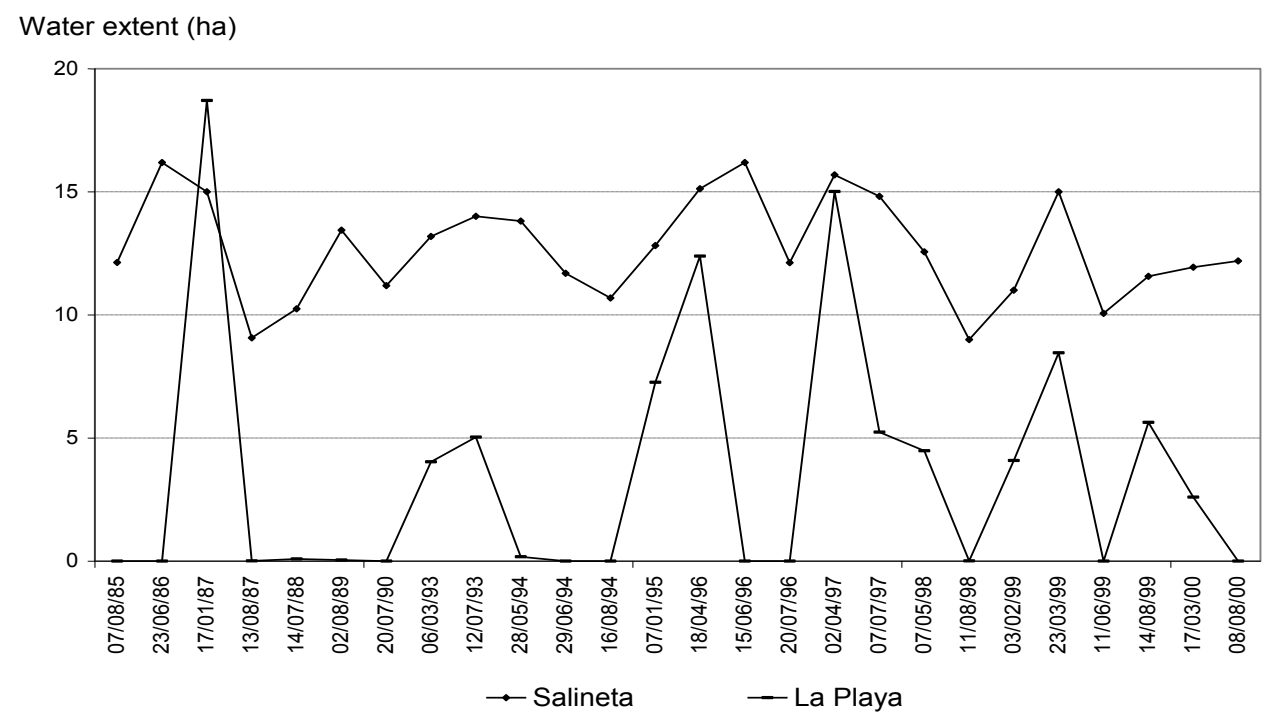

Figure 9. Contrasting patterns of flooding in two playa-lakes between 1985 and 2000. La Playa values were divided by10.

Moreover, our approach allows detecting and mapping five facies (Figure 10), catalogued by Castañeda et al. (2005) which will provide environmental information like (i) changes on the halophytes distribution, (ii) the evaporative surface in the playalakes for water balance simulations and (iii) invasion by agriculture, dumping, buildings, etc. 
Figure 10. Example of contrasting variation in the facies extent for two of the studied saladas from 1985 to 2000 .

Integration of this information in a Geographic Information System with other georeferenced information makes possible updating for effective surveillance of these protected areas and landscape planning. This information, essential for wetland monitoring and the protection of wildlife habitats, has been obtained for the first time in Monegros with the present study, yielding a profitable tool to study the evolution of these wetlands. 
Last, but not least, the remote sensing approach helped to field recognition of playa lakes and their features. Some advantages of this remote method to characterize the playa-lakes face to conventional field works were noticed. These five thematic classes enable to label different soil surface conditions, which are not easily detected in the field due to the playa-lakes inaccessibility and lack of perspective. Firstly, Water only can be delimited against Watery Ground by remotely sensed data. Secondly, Watery Ground can be confused in the field with Wet Ground because both of them can involve similar shining surfaces. Finally, mapping each cover extent in the field does not have a fair precision because there is a very limited sight from the playa-lakes edge and because the ever muddy bottoms can not be entered due to the low trafficability and the soil disturbance produced even by walking.

\section{Conclusions}

Landsat images overcame the scarcity of ground records about the water bodies in the arid playa-lakes of Monegros, Spain. This information is essential to know their natural hydric regime and to detect their change and any future impact from the newly irrigated lands. Moreover, the definition of facies overcomes the lack of a conceptual framework to assess the ecological status of the saladas.

The unsupervised classification of the satellite images, assisted with the expert analysis based on field knowledge, allows us to detect and quantify the ephemeral water and the other facies. The 26 analyzed images, distributed along 15 years from 1985 to 2000, are the largest existing facies records of these playa-lakes. This record could easily be extended in time and could reveal more seasonal details by using more images. 
The thematic maps produced have sufficient resolution for natural resource planning. The playa-lakes monitoring in winter, spring and summer shows that the water presence is variable, and rare in the summer. Since irrigation occurs mainly during summer, when playa-lakes are used to dry, satellite images of these months would be the most suitable for detecting the anomalous flooding of Monegros playalakes.

Scarce ground records were combined with our field knowledge to interpret the satellite data and to refine their thematic information with the limitation of the lacking of date coincidence. The remotely sensed techniques are more advantageous than field observations for the playa-lakes monitoring because it improves the cover field discrimination, and provides a more precise extent and it also characterizes all the depressions simultaneously.

Using classification software based not only on statistical but also on contextual data would improve the automatic obtaining of spectrally homogeneous and spatially compact classes with thematic meaning. For this purpose, the use of imagery with more spatial resolution is desirable. The field knowledge is essential to achieve a sound interpretation of the images. Periodic ground data would be helpful, but since the saladas look is extremely changeable, the remote sensing is a more consistent tool for monitoring.

\section{Acknowledgments}

This article is a result of the project REN2003-00742, funded by Ministerio de Ciencia y Tecnología, Spain, and is part of the preliminary works for the ESACategory-1 Project 2328, partially funded by the European Space Agency. 


\section{References}

Al-Khudhairy, D.H.A., Leemhuis, C., Hoffmann, V., Shepherd, I.M., Calaon, R., Thompson, J.R., Gavin, H., Gasca-Tucker, D.L., Zalidis, G., Bilas, G., Papadimos, D., 2002. Monitoring wetland dicht water levels using Landsat TM and ground-based measurements. Photogramm. Eng. R. S. 68 (8), 809-818.

Al Saifi, M.M., Qary, M.Y.H.T., 1996. Application of Landsat Thematic Mapper data in sabkha studies at the Red Sea coast. Int. J. Remote Sens, 17(3), 527-536.

Angel-Martínez, C., 1994. Aplicación de la teledetección en la localización de superficie de agua, CEDEX, Ministerio de Obras Públicas, Transportes y Medioambiente, Madrid, $70 \mathrm{pp}$.

Arlegui, L.E., Soriano, M.A., 2003. An example of a comparison between Thematic Mapper and radar images in the central Ebro basin. Int. J. Remote Sens, 24(3), 457-474.

Baghdadi, N., Bernier, M., Gautier, R., Neeson, I., 2001. Evaluation of C-band SAR data for wetlands mapping, Int. J. Remote Sens 22(1), 71-88.

Berga, A., 1993. Relaciones clima-agua-suelo-subsuelo en Monegros II. PhD Thesis, University of Lleida, Spain, pp.392 + annexes.

Birkett, C.M., 2000. Synergistic remote sensing of Lake Chad: variability of basin inundation. Remote Sens. Environ. 72, 218-236.

Brière, P.R., 2000. Playa, playa lake, sabkha: Proposed definitions for old terms. J. Arid Environ. 45(1), 1-7.

Bryant, R.G., 1999. Application of AVHRR to monitoring a climatically sensitive playa. Case study: Chott El Djerid, Southern Tunisia. Earth Surf. Proc. Land. 24, 283-302. 
Bryant, R.G., Rainey, M.P., 2002. Investigation of flood inundation on playas within the zone of Chotts, using a time-series of AVHRR. Remote Sens. Environ. 82, 360375.

Castañeda, C., 2002. Las saladas de Monegros sur estudiadas con datos de campo y de satélite, Consejo de Protección de la Naturaleza en Aragón, Zaragoza, 158 pp.

Castañeda, C., García, M.A. 2004. El balance de agua en humedales de medios áridos: aplicación a tres saladas de Monegros. In A. Fernández Uría (Ed.) Hidrogeología y Recursos Hidráulicos, Tomo XXVI, pp. 205-215.

Castañeda, C., Herrero, J., 2005. The water regime of the Monegros playa-lakes established from-ground and satellite data. J. Hydrol., in press.

Castañeda, C., Casterad, M.A., Herrero, J., 2001. Una metodología para el estudio de las saladas de Monegros Sur mediante imágenes de Landsat TM. In Teledetección, Medioambente y Cambio Global (J.I. Rosell and J.A. Martínez-Casasnovas, editors), Asociación Española de Teledetección, Proceedings of IX Congreso Nacional de Teledetección, Lleida, pp. 306-309

Castañeda, C., Herrero. J., Casterad, M.A., 2005. Facies identification within the playalakes of the Monegros desert, Spain, from field and satellite data. Catena, in press.

Chavez, P.S., 1988. An improved dark-object subtraction technique for atmospheric scattering correction of multispectral data. Remote Sens. Environ. 24, 459-479.

Chopra, R., Verma, V.K., Sharma, P.K., 2001. Mapping, monitoring and conservation of Harike wetland ecosystem, Punjab, India, through remote sensing, Int. J. Remote Sens 22(1), 89-98.

Chuvieco, E., 1996. Teledetección ambiental. Ariel Ciencia, 586 pp. 
Cihlar, J., Latifovic, R., Beaubien, J., 2000. A comparison of clustering strategies for unsupervised classification. Can. J. Remote S. 26(5), 446-454.

Drake, N.A., Bryant, R.G., 1994. Monitoring the flood ratio of Tunisian playas using Advanced Very High Resolution Radiometer (AVHRR) imagery. In Environmental Change in Drylands: Biogeographical and Geomorphological Perspectives, (Millington, A.C \& Pye, K., eds.), J. Wiley \& Sons Ltd, pp. 347364.

Dwivedi, R.S., Rao, B.R.M., Bhattacharya, S., 1999. Mapping wetlands of the Sundaban Delta and its environs using ERS-1 SAR data. Int. J. Remote Sens 20(11), 2235-2247.

Faci, J.M., Martínez-Cob, A., 1991. Cálculo de la evapotranspiración de referencia en Aragón. Diputación General de Aragón, 115 pp.

Frazier, P.S., Page, K.J., 2000. Water body detection and delineation with Landsat TM data. Photogramm. Eng. R. S. 66(12), 1461-1467.

Harris, A.R., 1994. Time series remote sensing of a climatically sensitive lake. Remote Sens. Environ. 50, 83-94.

Herrero, J., Snyder, R.L., 1997. Aridity and irrigation in Aragón, Spain. J. Arid Environ. $35,55-547$.

Houhoulis, P.F., Michener, W.K., 2000. Detecting wetland change: a rule-based approach using NWI and SPOT-XS data, Photogramm. Eng. R. S. 66(2), 205-211.

Kasishke, E.S., Bourgeau-Chávez, L.L., 1997. Monitoring South Florida wetlands using ERS-1 SAR imagery, Photogramm. Eng. R. S. 63(3), 281-291. 
Koch, M., 2000. Geological controls of land degradation as detected by remote sensing: a case study in Los Monegros, north-east Spain. Int. J. Remote Sens 21(3), 457473.

Landgrabe, D.A., 2003. Signal theory methods in multispectral remote sensing. J. Wiley \& Sons, $508 \mathrm{pp}$.

Lillesand, T.M., Kieffer, R.W., 2000. Remote sensing and image interpretation. Fourth ed. J. Wiley \& Sons, 724 pp.

Liu, L.G., Moore, J.M., 1990. Hue image RGB colour composition. A simple technique to suppress shadow and enhance spectral signature. Int. J. Remote Sens 11(8), 1521-1530.

Lunetta, R.S., Balogh, M.E., 1999. Application of multi-Temporal Landsat 5TM Imagery for Wetland Identification, Photogramm. Eng. Rem. S. 65(11), 13031310.

Munyati, C., 2000. Wetland change detection on the Kafue Flats, Zambia, by classification of a multitemporal remote sensing image dataset. Int. J. Remote Sens. 21(9), 1787-1806.

Nakayama, Y., Tanaka, S., Sugimura, T., Endo, K., 1997. Analysis of hydrological changes in lakes of Asian arid zone by satellite data, in Earth Surface Remote Sensing (Cecchi, G., Engman, E.T. and Zilioli, E., eds.). Proceedings of SPIE-The International Society for Optical Engineering, vol. 3222, Bellingham, Washington, pp. 201-210.

Pedrocchi, C. (Coordinator), 1998. Ecología de Los Monegros, Instituto de Estudios Altoaragoneses, Huesca, pp 430. 
Pueyo, J.J., 1979. La precipitación evaporítica actual en las lagunas saladas del área: Bujaraloz, Sástago, Caspe, Alcañiz y Calanda (provincias de Zaragoza y Teruel). Revista del Instituto de Investigaciones Geológicas, Diputación ProvincialUniversidad de Barcelona 33, 5-56.

Rao, B.R.M., Dwivedi, R.S., Kushwaha, P.S., Bhattacharia, S.N., Anand, J.B., Dasgupta, S., 1999. Monitoring the spatial extent of coastal wetlands using ERS-1 SAR data. Int. J. Remote Sens 20(13), 2509-2517.

Richards, J.A., Jia, X., 1999. Remote sensing digital image analysis. Third revised and enlarged ed., Springer, 363 pp.

Samper-Calvete, F.J., García-Vera, M.A., 1998. Inverse modeling of groundwater flow in the semiarid evaporitic closed basin of Los Monegros, Spain. Hydrogeol. J. 6, $33-49$.

Sánchez, J.A., Pérez, A., Martínez-Gil, J., 1998. Combined effects of groundwater and aeolian processes in the formation of the northernmost closed saline depressions of Europe: north-east Spain. Hydrol. Process. 12, 813-820.

Schneider, S.R., McGinnis, D.F., Jr., Stephens, G., 1985. Monitoring Africa's lake Chad basin with Landsat and NOAA satellite data. Int. J. Remote Sens. 6(1), 59-73.

Schütt, B., 1998. Reconstruction of palaeoenvironmental conditions by investigation of Holocene playa sediments in the Ebro Basin, Spain: preliminary results. Geomorphology 23, 273-283.

Swain, P.H., 1973. Pattern recognition: a basis for remote sensing data analysis (LARS information note 111572). West Lafayette, Indiana: the Laboratory for Applications of Remote Sensing, Purdue University. 
Swain, P.H., Davis, S.M., 1978. Remote Sensing: the quantitative approach. New York: McGraw Hill Book Company.

Valero-Garcés, B.L., Navas, A., Machín, J., Stevenson, T., Davis, B., 2000. Responses of a saline lake ecosystem in a semiarid region to irrigation and climate variability. Ambio 29(6), 344-350.

Valero-Garcés, B., Martí, C., García-Ruiz, J.M., González-Sampériz, P., Lorente, A., Begueria, S., Navas, A., Machín, J., Delgado-Huertas, A., Stevenson, T., Davis, B., 2001. Lateglacial and early holocene paleohydrological and environmental change along a humid-arid transect from the central Pyrenees to the Ebro valley (Spain). Terra Nostra 2001/3, 211-218.

Verdin, J.P., 1996. Remote sensing of ephemeral water bodies in western Nigeria. Int. J. Remote Sens 17(4), 733-748.

Yechieli, Y., Wood, W.W., 2002. Hydrogeologic processes in saline systems: playas, sabkhas, and saline lakes. Earth-Sci. Rev. 58, 343-365.

Zhang, M., Ustin, S.L., Rejmankova, E., Sanderson, E.W., 1997. Monitoring Pacific coast salt marshes using remote sensing. Ecol. Appl. 7(3), 1039-1053. 